\title{
THE TRIAL JUDGE DECREES MAINTENANCE
}

\author{
L. N. Turrentine*
}

In presenting a discussion of the factors which judges consider in maintenance orders it must be conceded at the outset that there is a dearth of legal precedents. However, a brief survey of the legal principles involved should be made and discussed before other factors are considered. Necessarily there are legal principles to consider as well as sociological principles. ${ }^{1}$

\section{General Observations}

It should be stated at the outset that a judgment or decree for support of children is a decree in personam, and hence there is no authority to make an order for support unless there has been personal service of process on the defendant or the defendant has personally appeared in the litigation. It is, of course, true that the order may be made against the plaintiff because of his voluntary appearance and submission of himself to the jurisdiction of the court. "The court may make a decree for the support and maintenance of a non-resident child where the parents have submitted to the jurisdiction of the court."2

The same rules as to support and maintenance apply equally in divorce, separate maintenance or annulment cases. Hereafter the term "divorce" will be used, bearing in mind the rule just stated.

While we think of the father as the one liable for the maintenance and support of a minor child, yet legally both the father and the mother have the responsibility and the court has power to make a decree against either one or both for the support and maintenance of the minor child, regardless of which party may be awarded its custody or whether or not custody is awarded to a stranger.

The support and maintenance award usually comes up in two ways. First, it may occur in a preliminary hearing either on an order to show cause or upon motion, when it is the desire to protect and provide for the minor pending the final hearing of the divorce insofar as it can be done without injury to the child. Secondly, it may come up at the time of the hearing of all of the evidence on the divorce and the making of the divorce decree. Thereafter it is subject to modification or change by

* LL.B., I913, University of Southern California; member of California Bar, rgr3-r930; Judge of the Superior Court, since 1930; Juvenile Court Judge, since 1936; President, California Judges Association (now California Conference of Judges), r934.

${ }^{I}$ Since the legal principles involved are really very few, very general and well known, the writer has resorted to a barest minimum of citation, restricted to familiar secondary authority. This policy, inter alia, avoids the temptation to cite California law-a natural temptation to one who has spent his cntire legal life in that jurisdiction.

${ }^{2} 27$ C. J. S. $1164, \$ 303$ (I94I). 
the court upon a showing made whenever there is the requisite change in the status of the parties or of the minor. Authority also resides within the equitable powers of the court (if it has general equitable jurisdiction), and frequently also by statute, to provide for the maintenance of children even though a divorce is denied. Likewise, it should be noted, the court once having acquired jurisdiction in personam of the party against whom the maintenance order is made or to be made, continues to have jurisdiction until the minor reaches his majority, regardless of the change of residence of the parties to a litigation. Furthermore, when the decree is silent as to the liability for maintenance the mother and father are still liable for the maintenance of the child. This is not only frequently recognized by statute but is also the general common law relating to parent and child. "The liability of parents for the maintenance and education of their minor children is not altered by a decree of divorce." 3 While an agreement between the husband and wife respecting the amount of support necessary to take care of a child is competent evidence and may be considered with all the other evidence in the case, it is not conclusive and binding upon the parties to the agreement. The right of minor children to support by the father is not affected by an agreement between the parents pending a divorce case. Any agreement releasing rights fixed by the decree for support is invalid so far as the child is concerned, although it might be an enforceable contract between the parties to the same, so long as the minor child does not suffer.

With this general survey of the law let us turn to the different situations presented to a court wherein an allowance for maintenance should be made when the parties and the minors are before the court.

\section{The Initial Alrowance}

The first situation relative to maintenance allowance usually met arises when the suit for divorce is first filed. This ordinarily comes on for hearing within a few days after the suit is filed and is presented either on an order to show cause or motion in the proceedings itself. The matter is then heard by the court and determined before any of the rights of the parties to the litigation in relation to the divorce are considered. Usually support is made in favor of the person who has custody of the child, pending the time when the divorce case is heard on its merits, unless that person has the duty and ability to support. In many jurisdictions the matter is determined on affidavits alone, although the court has full authority to consider both affidavits and oral evidence. If objections are filed to hearing the matter on affidavits, it is the better practice to have the matter heard on oral testimony. Generally speaking, the person asking that an allowance for maintenance of the minor be made must show not only the legal liability of the opposite party for maintenance, but also his or her own inability to adequately support the minor. Although the party's inability to support the minor is not binding or conclusive, it is one of the factors to be considered. The person against whom the order is sought

${ }_{27}$ C. J. S. $1198, \$ 319$ (B) (194I). 
must then, as a matter of defense, show by evidence or affidavit: either that he is legally not liable for the support of the minor; or, if he concedes this point, the extent of his resources. Only by such a showing can the court determine his ability to comply with any orders made against him. A detailed and itemized showing should be made in this regard. It is helpful to the court if this information is made available in the usual form in which household budgets are set up. It is not sufficient for a person to report a gross income and gross necessary expenditures. The gross income and the items of expenditure should be broken down and definitized in order that the court may determine for itself what is necessary for the person to retain for his own support and what may be reasonably charged against him for the support of the minor. This showing will ordinarily disclose the general status in life of the parties to the litigation. These items of course will vary with the position and the work of the person against whom support is sought.

With these factors before the court, it must first be determined what is necessary for the support of the person against whom the order is sought so that he may continue to work and earn enough to comply with any court order. He must have at least enough to keep body and soul together and sufficient inducement to continue to labor and work in order that he may make sufficient to take care of himself and comply with the order. The court cannot absolutely kill initiative and expect compliance with any order which it may make in regard to the support of a minor. Viewed as a practical matter, unless this factor is given due consideration by the court, the party will probably leave the jurisdiction of the court, or disappear, leaving his whereabouts unknown. It has been the writer's experience that the person against whom an award is to be made is sure that he must have "that operation" at once, although he may have neglected it for the ten years last past.

Having determined this basic point the court then may look to the party's other obligations and decide whether they are absolutely necessary for his ultimate protection. It is from the residue alone that an order for support may be enforced. Should he depend for his livelihood on the work of a traveling salesman, then necessary automobile expense will be a necessary charge ahead of an order for support. On the other hand, should the person have a business at his own home, then automobile allowance would not come ahead of an order of maintenance. It is also proper to ask and determine the resources and income of the person who has custody of the child (unless it be a stranger). Should the minor have an independent income of its own such as from a trust or otherwise, this factor may also be considered at this hearing.

The court having determined from the hearing the amount reasonably available for the support of a minor, it should then turn its attention to how much should be ordered. The court will, at this time, consider the social status of the parties and consequently that of the child, and if there are sufficient resources to maintain it on that same general level an order will be made accordingly. Again, circumstances vary with the cases. Assuming that a girl is in her senior year at high school 
and about to graduate and that the resources are sufficient, the court will make an order not only to give her enough to eat but also to see that she has all of the reasonable items usually expended on a girl at this period in her life; that she may graduate happily and on a comparative basis with her classmates. It may include party dresses, graduation gown, flowers, gifts and all of the things that the ordinary girl in that particular status of life receives at that particular time in her life. Should the mother have custody and be herself working, as is so often the case under present war conditions, this fact will be given consideration and she will be expected to pay out of her income a reasonable amount for the support of the youngster, even though she may have custody herself. Special circumstances are also considered at this time such as emergency medical and dental services. At this stage of the proceedings where the parents do not have any income but have property, either joint or separate, the order for maintenance may take this fact into consideration and an order may be made that it be paid out of the joint or separate funds of the parties liable therefor, encroaching on the corpus if necessary. It might be observed that it is customary specifically to insert in any such order that it is binding only until the trial of the case on merits or until the further order of the court. This is a mere restatement of the law anyhow, but the fact that it appears in black and white oftimes avoids controversy and confusion.

There obviously can be no hard and fast rule in these maintenance orders, other than that the amount allowed for the support of minor children must be reasonable and must take into consideration all of the matters heretofore discussed. It must obviously be within the power of the person against whom the order is made to comply therewith. This of course will vary with times and conditions. Obviously the court must take into consideration what it knows about the cost of living at the particular time and place and the general economic condition of the country. An order made during the height of the depression, say in 1933 or 1934, would be obviously entirely different from an order made today when living costs are higher and the income is immeasurably higher for all persons concerned. The judge passing on the particular case should be familiar with charges made by institutions and boarding homes taking care of children both on public placements and private placements. It has been the general experience of the writer that when the cost in a boarding home or public placement is around $\$ 30.00$ per month, the cost of private placement in the same character of institution is around $\$ 45.00$ per month. Consideration should also be given to the number of children in the custody of a person for whom an award is made. It is obvious that the cost per child is more when one child alone is taken care of than where three, four, five, six or seven are maintained in a group.

In the final analysis the amount is left to the judicial discretion of the judge and unless it is affirmatively shown that he has abused this discretion a reviewing court will not alter an award of this character as made by the court below. 


\section{The Pernianent Award}

We will now turn our attention to the second phase of the problem under discussion, viz., what orders are to be made for the maintenance for children of divorced parents at the time of the hearing of the divorce case on its merits. One may expect the trial of a divorce case on its merits, if contested, to come on for trial in a period anywhere from six weeks to four months after the preliminary hearing. Then for the first time the parties have the opportunity to present all of the evidence in the case, not only as to the merits of their own case, but as to the welfare of the children. The judge also has the opportunity to observe each witness and to test the veracity of the witness under his own-scrutiny, after there has been a complete opportunity of cross examination of the witness by both parties. If he has made a preliminary order pending the trial of the case on the merits, he has had the opportunity to observe not only the manner in which the order has actually been carried out by the parties, but also their spirit and attitude toward it and toward the children during that period. Also, the court at this time is interested in a longtime program for the children. He must consider not only their necessities and welfare at the time of the immediate trial, but also must give consideration to the different seasons of the year such as the requirements in vacation and school periods, the time of temporary visits with the party who does not have the permanent care and custody such as week-ends or vacation visits with the opposite party, the age of the minors and their capacity to earn something for themselves and the change in the legal obligations of the parties after a divorce is granted. This last item is particularly appropriate for review at this time as changes will necessarily be made in annual or semi-annual recurring charges which add to a person's estate or property holdings, such as life insurance premiums or annuities, or purchase of capital assets such as a home, an automobile, or other property of that character which is often denominated nonconsumable.

At this time consideration is also given as to whether the children need special training or have special talents which merit development. If finances permit, there is no reason that a parent should not be ordered to make sufficient arrangements for the support and maintenance so that special talents may be developed. The child should be given the best opportunity to build for his future within the resources of the persons who owe him the obligation of support. It has long been the sociological view of the writer that parents do not have "rights" over their children; rather, they are trustees charged with the custody of their children for a brief portion of their lives and under an obligation to fit them to meet life in their own way and become happy and useful citizens who have something to contribute of themselves to the welfare of the world. Opportunity to enforce that concept is given when the parties or parents come before the court and thereby admit their failure to handle the matter in their own way. The responsibility then passes to the judge who is trying their case. 
From what has been said it becomes apparent that the same factors must be considered when permanent order for maintenance is made as when it is made at a preliminary stage of the game, with the added assurance that the judge has had the opportunity more carefully to weigh all of the factors and come to the truth of the contentions between the parties. Then it becomes his duty to give effect to the same factors outlined in the first portion of this article and be sure that they occupy their proper position in the long-time program which must be planned for the child of the broken home.

It should be noted that the jurisdiction over the case stays with the court throughout the period that the child is a minor and the order may be altered, changed or modified from time to time by the court as conditions of the parties change. It may be increased or reduced, in accordance with the new circumstances and ability of the party against whom the award is made, as well as the position and needs of the person who has the custody of the child.

\section{ILLUSTRATIVE INSTANCES}

As illustrative of both the adequacy and inadequacy of the court in dealing with the real human problems of taking care of one's children when bitterness enters into the relationship between the parents, two cases selected by the writer from hundreds of hearings may be cited as examples.

John Armstrong and Mary Armstrong (names fictitious) were married in 1922. By 194r they were blessed with seven children, ranging from nineteen to six years of age. Until then, the family had lived on an income rather meager, even depending somewhat on public help during the depression of the thirties. Early in $194 \mathrm{I}$ the family moved to California and the father and two oldest children entered into defense work. All were still living at home and the family income was now about $\$ 100.00$ a week. Late in I94I the oldest boy entered the armed services and the next oldest followed in January of 1942 . This left the husband and father, earning about $\$ 47.00$ a week, to take care of his wife and five remaining children. John turned all of this sum over to Mary to handle, retaining (with Mary's consent) \$5.00 which he placed in a savings account, $\$$ r.oo per week for a street car pass, and $15 \mathrm{c}$ per day to spend in such riotous living as he saw fit. Mary put up his lunch and did all of the family buying and washing. Perhaps the new found prosperity or the desire to augment the same was the cause; perhaps there were other considerations; at any rate Mary began secretly to seek the company of service men. After being caught twice by John, and twice forgiven, she was found a third time with a service man in a most compromising situation. Thereupon John filed suit for divorce and stopped turning over any money to his wife except \$ro.00 per week, with which she was expected to support the children. She countered with a cross complaint and cited her husband into court on an order to show cause why the allowance for the support of the children should not be increased to $\$ 35.00$ per week, and for attor- 
ney's fees and costs. On the hearing John made a showing that he must have a minimum of

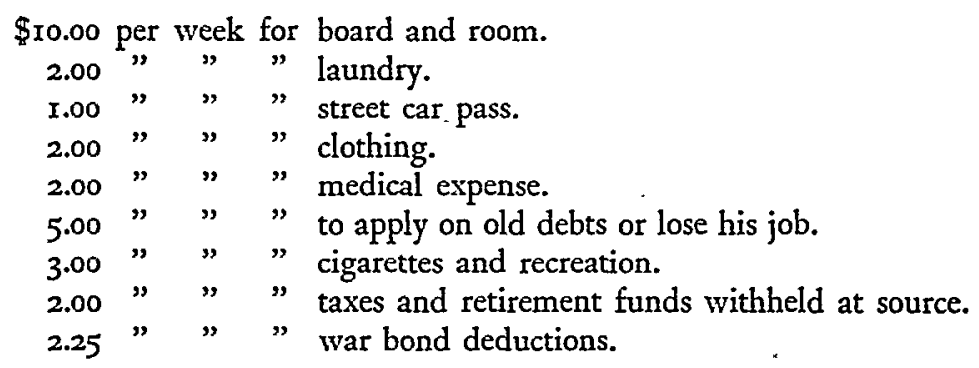

Total $\$ 29.25$ Amount required by husband to maintain himself when living apart from his own home.

The wife's necessary costs of living were itemized as follows:

$\$ 7.50$ per week rent (they were living in meager quarters).

17.50" " groceries and household supplies.

$5.00 " \Rightarrow$ shoes and clothing for self and 5 children.

$2.00 "$ " medical expense.

2.00 " " recreation, self and children. (Note: Husband countered that the wife's recreation with service men was remunerative instead of a legitimate expense.)

$2.00 "$ " for transportation (necessary for children in school, self shopping, etc.).

$3.00 "$ " for incidentals.

Total $\$ 39.00$ Minimum amount required by wife for support of self and children.

. The total claimed by both, it is seen, is $\$ 68.25$, which exceeds the admitted income of $\$ 47.00$ a week by $\$ 21.25$. In addition, the husband was required to pay the costs and attorney fees of himself and wife. Obviously, there is not sufficient money to take care of the minimum requirements claimed by both the husband and wife. Therefore the following approach was made. After explaining to the parties that it was impossible to meet the necessities of either party, the court proceeded to determine the amount that the husband must have to keep body and soul together. The result was as follows:

$\$$ ro.00 per week for board and room allowed.

\$2.00 per week for laundry disallowed. (He would have to do his own.)

I.00 per week for street car pass allowed.

2.00 per week for clothing disallowed. (Would have to wear old clothes pending trial.)

2.00 medical expense disallowed, to be reconsidered if actually incurred. 


\begin{tabular}{|c|c|c|}
\hline 2.00 & & per week allowed to apply on old debts. \\
\hline & 3.00 & disallowed to apply on old debts. \\
\hline & 3.00 & cigarettes and recreation disallowed. \\
\hline 2.00 & & per week for taxes and retirement fund allowed. \\
\hline 2.25 & & per week for war bonds allowed. \\
\hline 2.00 & & per week to pay on costs allowed. \\
\hline 5.00 & & per week to apply on attorney fees allowed. \\
\hline 4.25 & & Total allowed. \\
\hline
\end{tabular}

This amount, taken from the $\$ 47.00$ income, leaves $\$ 22.75$ weekly available for the wife and children. This is admittedly inadequate, but all there is has been consumed. It must be observed here that now there was nothing available for augmenting the savings account, and the past savings were consumed in attorney fees and costs.

On account of the condition of the trial calendar, the trial of the case was set about five months ahead.

After twelve weeks, during which time all parties tried to abide by the court order and live on the allowed sums, the husband and wife appeared at the judge's chambers one morning and asked for an interview. They wanted the judge to effect a reconciliation for them, as neither one of them or the children could get along on the money available and allowed for each, and they wanted to keep the home together. An interview was held and when the husband was asked his real grievance he said that it was his wife running around with service men, and he wanted that stopped. When asked her attitude, her reply was, "Well, Judge, I will try to quit doing that, but it's going to be hard." Mary was then asked her chief grievances against John, and she replied that she wanted the money to spend, as she had to do the buying for the family and could spend the money more intelligently than the husband. John said that this was all right, but he wanted to keep. car fare, the $\$ 5.00$ to deposit in the savings bank and the $15 \mathrm{c}$ per day for "recreation." Mary said that this was fair, but that she wanted John to show her the pass book every week after making the deposit. Here John completely balked and said he wouldn't show her the pass book, as "he'd be damned if he would be henpecked." The judge hated to see the reconciliation fail at this point and said, "You don't object to her knowing that you make the deposit and the amount in the savings account do you?" "No, I don't object to her knowing it but she can't ask me about it and demand to see the pass book" was the reply. The judge then suggested that Mary never again ask about the money in the bank or to see the pass book, but that John leave the pass book in the cupboard and, if Mary wanted to see it, she do so in the absence of John and while he was at work. This appealed to them as fair. Her desire to know the condition of the savings account was satisfied and John did not consider himself "henpecked." They kissed, left together, reconciled and happy and, so far as I know, Mary was successful in her "try to quit." John has not 
been "henpecked." For over two years the home has been kept together and the children have had the security of a father and mother actually taking care of them. It is important that the judge take the time and patience to explain to the parties the reason for the application of the fundamental economics employed and why an actual hardship often must be imposed on both parties when the family income must be divided.

Although the court has the power to make orders, sometimes they are ineffectual, and are thwarted in spite of all that the law can do. Peter Small and Clara Small (names fictitious) during their married life had acquired considerable property which was managed by the husband and kept in bearer securities. In 1940 when Mrs. Small filed a suit for divorce they had two daughters, one of whom was about to enter high school and the other about to enter college. Peter was an engineer, working for a salary of $\$ 10,000$ a year. At the preliminary hearing on the motion for support, etc., the wife requested that she be allowed to live in the home and have $\$ 350.00$ a month for support of herself and children and that the defendant be enjoined from disposing of the bearer securities; also the husband was ordered to pay $\$ 500.00$ for attorney fees and costs. To this the husband made no objection and the order was made. An answer was filed and the case set for trial some four months ahead. Prompt and full compliance with the preliminary order was made by the defendant. About two days before the trial the defendant disappeared, taking with him the bearer securities. At the trial the final order was made the same as the preliminary order. When the defendant was found, he had left the jurisdiction of this court and was in a jurisdiction where failure to comply with a California court order and failure to support children are not crimes and not offenses for which a person within its borders was extraditable. Suit on the California judgment in the foreign jurisdiction resulted in an immediate removal to another foreign jurisdiction with similar laws, and the whereabouts of the defendant is now unknown. In spite of all that competent and eminent counsel could do, and all processes of law which they could employ, it was and has been impossible to force the defendant to comply with the court order or support his children. Hence the mother has had to go to work, as has the older daughter who has lost a college education.

Of these two cases, one was a success and the other a failure from the standpoint of those who wanted to work out a plan for the parties. But note that the failure was due to a series of circumstances beyond the power of the law to control -at least, the law as it is at present; query, whether making extradition available would help. Given interested judges and lawyers, solution can be worked out in the great majority of cases. An up-to-date set of rules of law is also a great advantage. Even with these aids, however, some cases still remain impossible of solution.

Finally, it may be said that outside of the legal questions affecting the jurisdiction of the court to act in a particular case, very little help toward the solution of 
a new situation can be obtained from any of the adjudicated cases. This is because the whole matter is equitable in its nature as well as in its application and enforcement, and because of the broad underlying principle that the whole matter is within the sound, legal discretion of the chancellor deciding the case. This discretion cannot and will not be changed or reversed except on an affirmative showing of abuse thereof. 